\title{
Pelatihan Manajemen Kehumasan bagi Sekolah Menengah Kejuruan (SMK) Negeri 4 Pekanbaru
}

\author{
Ulmi Marsya*, Johan Faladhin, Dewi Martina \\ Program Studi Hubungan Masyarakat, Fakultas Ilmu Komunikasi \\ Universitas Muhammadiyah Riau \\ email: ulmimarsya@umri.ac.id
}

\begin{abstract}
Vocational High School (SMK) is held as a secondary school from SMP / MTs in accordance with their talents, interests and abilities in order to meet the needs / job opportunities that are and will develop in the area. Maximizing the potential of vocational schools can be done by carrying out the public relations function to shape the image and reputation of the school so that it is able to compete with high schools (SMA). Especially in SMK $N 4$ Pekanbaru which has great potential to be socialized to the public. In connection with the Public Relations Study Program is committed to contributing with institutions including schools to be able to carry out their public relations functions properly.
\end{abstract}

Key words: Management Public Relations, School Public Relations, Corporate Image

\section{Abstrak}

Sekolah Menengah Kejuruan (SMK) diselenggarakan sebagai sekolah lanjutan dari SMP/MTs sesuai dengan bakat, minat dan kemampuan dalam rangka memenuhi kebutuhan/kesempatan kerja yang sedang dan akan berkembang pada daerah tersebut. Pemaksimalan potensi dari SMK dapat dilakukan dengan menjalankan fungsi kehumasan untuk membentuk citra dan reputasi sekolah agar mampu bersaing dengan Sekolah Menengah Atas (SMA). Terutama pada SMK N 4 Pekanbaru yang memiliki potensi besar untuk dapat disosialisasikan kepada masyarakat. Berkaitan dengan Program Studi Hubungan Masyarakat berkomitmen untuk berkontribusi dengan institusi termasuk sekolah untuk dapat menjalankan fungsi kehumasannya dengan baik.

Kata kunci: Manajemen Kehumasan, Humas Sekolah, Citra Institusi

\section{PENDAHULUAN}

"Give a man a fish and you will feed him for a meal. But teach a man how to fish, and you will feed him for life". Kata bijak ini yang menyiratkan makna bahwa ketika kita berikan pada seseorang seekor ikan, sama halnya dengan kita hanya memberinya hanya sekali makan saja akan tetapi apabila kita mengajari seseorang bagaimana caranya memancing ikan, maka kita seperti telah memberi dia makan seumur hidupnya. Hal ini seperti halnya dunia pendidikan, para murid disuapi ilmu yang kemudian akan membekali kehidupannya dimasa depan. Terutama pada Sekolah Menengah Kejuruan (SMK) yang bukan hanya membekali siswa-siswinya pemahaman keilmuan secara teoritik, namun juga membentuk skill khusus yang kemudian mampu melahirkan produkproduk yang mumpuni.

Sekolah Menengah Kejuruan (SMK) diselenggarakan sebagai sekolah lanjutan dari SMP/MTs sesuai sedang dan akan berkembang pada daerah tersebut. SMK merupakan salah satu pilihan siswa lulusan SMP untuk melanjutkan studinya. Akan tetapi 
peminat sekolah SMK dianggap masih kalah bila dibandingkan dengan peminat Sekolah Menengah Atas (SMA) Hal Tersebut disebabkan kurangnya sosialisasi kepada masyarakat mengenai potensi yang dimiliki SMK, bahwa lulusan SMK memiliki bekal yang lebih untuk terjun ke dalam dunia kerja dibandingkan SMA. Oleh karena itu SMK memerlukan usaha lebih keras untuk dapat menarik minat masyarakat agar mendapatkan kepercayaan bahwa sekolah yang bersifat kejuruan lebih menjanjikan masa depan. untuk itu diperlukan suatu fungsi humas di dalam sekolah sebagai media sosialisasi.

Hubungan Masyarakat (HUMAS) berperan penting dalam proses Penyelenggaraan pendidikan. Keberadaan Humas pada dasarnya ialah membangun reputasi yang merupakan asset penting dan wajib dimiliki oleh lembaga sebagai bukti keberadaan dan kualitas lembaga. Reputasi sekolah menunjukan kualitas pendidikan sekaligus pencapaian prestasi sekolah sebagai indikator keberhasilan program pendidikan sekolah. Sandra Oliver (2007:4)

Menyebutkan Humas adalah manajemen reputasi organisasi. Humas mengidentifikasikan persepsi yang dipegang oleh organisasi dan member informasi mengenai kinerja organisasi kepada semua audiens yang relevan. Humas menyangkut pengembangan reputasi yang pantas untuk sebuah organisasi yang didasarkan pada kinerja. Makadari itu, sekolah sebagai salah satu instansi pendidikan juga membutuhkan fungsi manajemen humas yang lebih matang dalam rangka membentuk reputasi dan menonjolkan keunggulannya dibandingkan dengan yang lain, terutama SMK yang seharunya dapat menonjolkan keunggulan mereka dalam hal kesiapan siswa dalam dunia pekerjaan serta produk yang dihasilkan oleh siswa-siswi mereka. Manajemen SMK didesain untuk mencapai tujuan utama SMK secara efektif dan efisien, yaitu menyiapkan lulusan yang siap memasuki dunia kerja dan bekerja. Merencanakan dan melakukan program sedekat mungkin dengan kondisi ditempat kerja merupakan tugas penting SMK. Aktivitas Kehumasan Sangat Penting dalam mengkomunikasikan, menyebarluaskan, sebagai perantara dengan pihak luar dalam mempromosikan keunggulankeunggulan yang dimiliki sekolah. Seperti halnya SMK N 4 Pekanbaru yang tentunya memiliki potensi besar untuk dapat ditawarkan kepada masyarakat.

\section{IDENTIFIKASI MASALAH}

Adapun masalah yang ingin diselesaikan dalam pengabdian ini adalah SMK memiliki potensi yang besar dalam memberikan bekal yang lebih matang bagi siswa-siswinya agar lebih siap menghadapi dunia kerja. Potensi ini sangat penting disosialisasi kepada masyarakat melalui manajemen humas yang baik sehingga akan membentuk reputasi sekolah yang lebih baik sehingga dapat menarik minat masyarakat untuk menyekolahkan anak mereka di SMK terutama dalam hal pengembangan skill dalam dunia kerja. SMK N 4 Pekanbaru merupakan salah satu SMK Negeri yang memiliki potensi besar karena menawarkan beberapa jurusan yang sangat potensial dalam dunia kerja. Terdapat 7 program keahlian yang ditawarkan seperti konstruksi kayu, teknik computer jaringan, design komunikasi visual, produksi kria tekstil, design produksi kria kayu, busana butik, dan akuntansi.

\section{METODE PELAKSANAAN}

Tahapan pengabdian yang dilakukan dalam kegiatan Pelatihan Manajemen Kehumasan Sekolah di 
Pekanbaru, dimulai dari penentuan objek pengabdian yakni sekolah SMA/SMK/MA. Kemudian setelah berdiskusi dan menimbang, maka diputuskan pengabdian masyarakat dilakukan di SMK Negeri 4 Kota Pekanbaru. Berdasarkan data yang didapat bahwa sekolah tersebut belum memahami fungsi dan peran profesi humas dalam sebuah intitusi sekolah. Berikutnya, dosen prodi Hubungan Masyarakat yang melakukan pengabdian ini mengunjungi pihak sekolah untuk melakukan survey, meminta data dan temu ramah dengan perangkat sekolah, baik Kepala Sekolah, Wakil Kepala Sekolah, segenap Guru, perwakilan siswa dari OSIS dan terutama pada Kepala Bagian Kehumasan Sekolah yang kemudian menyepakati untuk melakukan pengabdian masyarakat di sekolah tersebut pada tanggal yang sudah di sepakati bersama.

Teknis pelaksanaan pengabdian dilakuan oleh para dosen Program Studi Hubungan Masyarakat dengan menyampaikan beberapa materi terkait dengan pengenalan lingkup profesi humas, fungsi dan peran humas sebuah institusi, serta peluang dan tantangan profesi humas kedepan. Selain para dosen dari Program Studi Hubungan Masyarakat, beberapa mahasiswa juga diikutsertakan dalam kegiatan ini dengan melakukan seleksi terlebih dahulu, yakni dari mahasiswa Himpunan Mahasiswa Prodi Humas. Kegiatan ini diharapkan dapat memberikan pemahaman terhadap masyarakat terutama terhadap sekolah di tingkat SMA/SMK/MA yang dalam hal ini difokuskan kepada SMK Negeri 4 Pekanbaru. tentang pentingnya pemahaman sekolah terhadap peran dan fungsi kehumasan yang masih dianggap belum memiliki "taring" terutama pada institusi pendidikan. Kegiatan pengabdian kepada masyarakat ini dilaksanakan dalam satu periode yakni dimulai dari bulan Juli s/d September 2018.

HASIL DAN PEMBAHASAN

Pelatihan Manajemen Kehumasan Sekolah yang dilaksanakan pada tanggal 31 Agustus 2018 merupakan salah satu bentuk perhatian program studi Hubungan Masyarakat Fakultas Ilmu Komunikasi Universitas Muhammadiyah Riau untuk membagi keilmuannya kepada institusi terutama Sekolah. Kegiatan pengabdian ini diadakan di SMK N 4 Pekanbaru dan ditujukan kepada seluruh elemen sekolah seperti para guru, murid, pegawai, dan staf Humas sekolah agar dapat bersinergi membentuk citra positif sekolah. Materi pengembangan manajemen kehumasan sekolah disampaikan oleh Johan Faladhin, S.I.Kom.,M.I.Kom. selaku ketua tim pengabdian kepada masyarakat. Pemaparan materi dilakukan dengan dua cara yaitu melaui power point dan melalui video.

Pelatihan Manajemen Kehumasan Sekolah yang diadakan oleh Program Studi Hubunngan Masyarakat ini dihadiri oleh 24 peserta yang bersal dari perwakilan setiap jurusan sekolah, guruguru, serta staf humas SMK N 4 Pekanbaru.

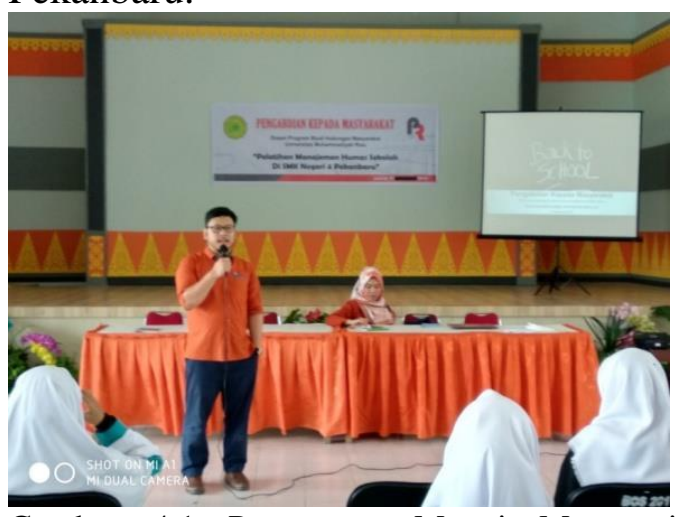

Gambar 4.1 Pemaparan Materi Mengenai Manajemen Humas Sekolah

Materi pertama yang disampaikan oleh Pemateri adalah mengenai 
pemahaman tentang Humas dan mengapa humas sangat dibutuhkan oleh sebuah institusi termasuk sekolah. Materi pengenalan tentang Humas disampaikan dengan menggunakan sebuah video. Video yang berjudul "What is Public Relations" itu dibuat dalam bentuk sketsa dan berdurasi 2 menit 28 detik yang menceritakan fungsi Humas bagi institusi dengan alur seperti bagan dibawah ini:

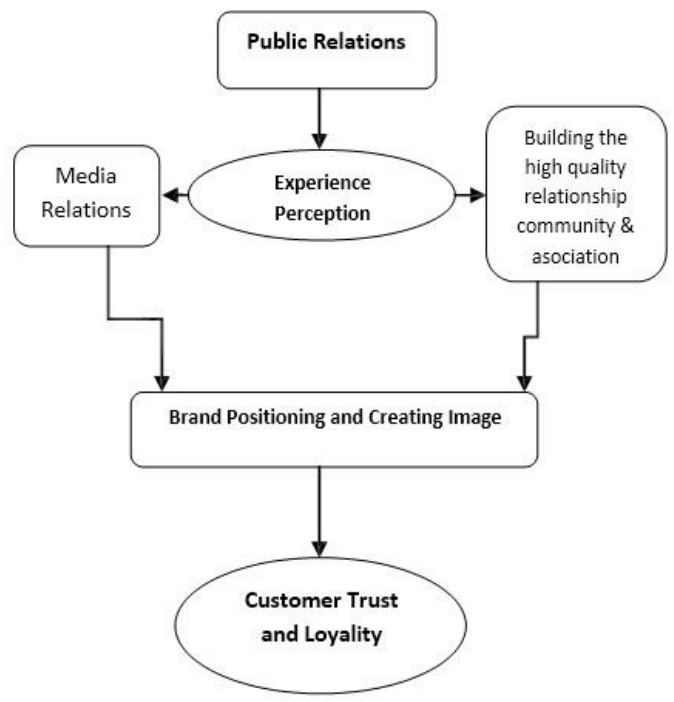

Gambar 4.2 : Peran Public Relations

Pertama-tama

pemateri menjelaskan betapa pentingnya "experience perception" atau persepsi yang tercipta melalui pengalaman publik terhadap sebuah institusi Karena dari pengalaman tersebut maka akan terbentuk sebuah kesan tersendiri dihati publik terhadap sebuah institusi. Dalam hal menciptakan experience perception, public relations biasanya mengandalkan dua macam cara, pertama, memanfaatkan media sebagai corong komunikasi untuk menyampaikan pesan-pesan positif mengenai institusi kepada masyarakat. Media massa seperti televisi, Koran, radio, internet dan lainnya yang notabene berfungsi sebagai alat Media Relations, Experience, Perception, Brand Positioning and Creating Image, Customer Trust and
Loyality, high quality relationship community \& association komunikasi massa yang mampu menjangkau khalayak luas untuk penyebaran informasi. Sehingga penting Humas untuk menjalin hubungan yang baik dengan media atau biasa disebut sebagai media relations.

Kedua, yang menjadi sangat esensial dalam peran humas adalah menjalin hubungan yang harmonis dan baik dengan mayarakat dan berbagai macam asosiasi. Misalnya dengan cara memberikan pelayanan yang baik, fasilitas dan kualitas yang mumpuni serta membuat program corporate social responsibility (CSR). Kualitas hubungan yang baik makan akan memberikan kesan dari pengalaman keterlibatan dengan institusi menjadi baik. Experience perception dan kesan yang didapatkan masyarakat mengenai sebuah institusi kemudian akan menempatkan brand image institusi dalam masyarakat. Misalnya dalam konteks institusi pendidikan seperti SMK N 4 akan melekat atau terbranding dibenak masyarakat sebagai SMK yang memiliki khas dapat mencetak lulusan yang berkualitas dan memiliki skill khusus dibidang tertentu sesuai dengan jurusan yang terdapat didalamnya yang mana hal ini lah yang membedakan SMK N 4 Pekanbaru dengan sekolah SMA atau SMK yang lainnya. Hal inilah yang disebut sebagai brand positioning atau creating image. Efek jangka panjang atau goal yang akan dicapai setelahnya tentunya adalah kepercayaan masyarakat terhadap intitusi dan loyalitas. Misalnya dengan merekomendasikan sekolah tersebut kepada rekan-rekannya.

Materi selanjutnya adalah mengenai manajemen humas atau management Public Relations. Pemateri menjelaskan beberapa tahapan dari manajemen humas. Seperti fact finding, yaitu menemukan 
fakta-fakta lapangan yang akan menjadi permasalahan bagi institusi. Misal dalam konteks minat masyarakat kepada SMK atau SMA. Data di lapangan ditemukan bahwa lebih banyak masyarakat lebih memilih menyekolahkan anaknya di sekolah SMA dibandingkan SMK. Padahal sekolah SMK menawarkan lebih dari hanya materi secara teoritik dalam kegiatan belajar mengajar karena lebih menekankan pada praktik untuk membentuk softskill siswa-siswi sehingga siap menghadapai dunia kerja. Fakta ini dipicu oleh salah satunya mengenai image siswa-siswi SMK dimata masyarakat lekat dengan tawuran sehingga orang tua enggan menyekolahkan anaknya di SMK.

Image negative tersebut harus dituntaskan melalui beberapa cara. Maka pada tahap ini akan masuk pada tahapan planning and strategy. Perencanaan yang matang dan strategi yang jitu untuk merubah citra negative mengenai sekolah SMK tersebut agak menjadi citra positif. Misal lebih menekankan pada keunggulan siswasiswi lulusannya dalam hal softskill dan siap menghadapi dunia kerja. Segala perencanaan dan strategi mengenai citra seperti apa yang ingin kita sampaikan kepada masyarakat, seperti yang telah disusun tersebut harus dapat kita sampaikan kepada masyarakat. Pada tahapan ini disebut sebagai communicating. Dalam hal mengkomunikasikan atau menyampaikan informasi kepada masyarakat, maka media massa memiliki peran yang sangat signifikan untuk menyebarluaskan informasi. Makadari itu humas harus menjalin hubungan yang baik dengan media atau media relations.

Tahapan terakhir adalah evaluating program atau melakukan evaluasi pada program-program yang telah dijalankan. Hal ini dilakukan agar dapat mengetahui apa kelebihan dan kekurangan program tersebut serta menakar bagaimana efek yang dihasilkan melalui program-program tersebut. Selain itu juga mengevaluasi bagaiamana media membentuk citra institusi dengan melakukan media monitoring. Misalnya bagaimana kemudian media memberitakan sekolah SMK pada umumnya dalam masyarakat. Apakah lebih kepada citra negatif seperti tukan tawuran atau sudah mulai lebih mengedepankan kualitas lulusan yang langsung memiliki skill khusus dan siap kerja.

Pemaparan materi ini ditujukan agar dapat mensinergikan segala elemen sekolah agar dapat menjadi humas bagi sekolahnya. Misalnya sebagai murid didik. Dengan adanya image negatif dalam masyarakat mengenai murid SMK maka sebagai murid dan bagian dari sekolah, maka mereka harus lebih mengedapankan prestasi belajar dan menjauhi hal yang berhubungan dengan kekerasan dan pertikaian antar sekolah. Disini murid dapat berperan sebagai humas sekolah agar dapat membentuk citra positif sekolah mereka. Kemudian guru-guru juga berperan dalam membentuk image sekolah dengan memberikan pendidikan yang baik dan mencetak siswa siswi yang berkualitasi dan mampu bersaing. Dalam hal ini guru juga berperan menjadi humas Sekolah dengan membantuk membentuk image positif sekolah. Kemudian yang paling penting adalah staff kehumasan yang mampu memberikan informasi yang positif kepada masyarakat mengenai keunggulan-keunggulan yang dimiliki oleh sekolah. Dan mampu menjadikan produk-produk sekolah SMK memiliki nilai jual yang tinggi dalam masyarakat. Makadari itu seluruh elemen sekolah harus turut andil dalam mengikuti pelatihan manajemen kehumasan ini. 
Selain pemanfaatan SDM yang dimiliki oleh sekolah, pelatihan manajemen kehumasan sekolah ini juga memberikan masukan kepada seluruh peserta bagaimana caranya memanfaatkan asset serta teknologi agar dapat dijadikan sebagai sarana untuk membentuk atau meningkatkan citra sekolah. Misalnya, SMK 4 Pekanbaru memiliki 7 jurusan sekolah, salah satunya adalah Design Komunikasi Visual (DKV). Sebagai jurusan design, output jurusan ini adalah bagaimana menciptakan design komunikasi mengenai informasi sekolah untuk disampaikan kepada masyarakat. Misalnya dengan membuat penggamabaran sekolah secara visual melalui berbagai media seperti poster, brosur, bahkan melalui media digital. Terutama pada era komunikasi digital saat ini, maka kesempatan sekolah untuk menciptakan medianya sendiri lebih terbuka lebar. Jurusan ini akan sangat potensial untuk membantu masyarakat mendapatkan informasi mengenai sekolah dan dapat membedakan sekolah SMK N 4 dengan sekolah lainnya. Karena tujuan dari design komunikasi visual adalah untuk menyampaikan pesan secara kreatif agar mendapat atensi yang lebih karena memanfaatkan visualisasi agar mudah diingat oleh masyarakat.

Pelatihan Manajemen Kehumasan Sekolah dalam rangka memanfaatkan segala elemen sekolah untuk menjadi "Humas" bagi sekolahnya dirasa akan sangat bermanfaat bagi institusi seperti sekolah agar dapat mempertahankan reputasi dan mendapat kepercayaan dalam masyarakat dengan memanfaatkan semua elemen yang ada disekolahnya. Pelatihan ini mendapat apresiasi dari bagian kehumasan SMK N 4 Pekanbaru karena dapat membantunya meningkatkan fungsi humas yang sesunggunya. Pelatihan ini diakhiri dengan penyerahan piagam penghargaan bagi sekolah SMK N 4 Pekanbaru sebagai bentuk apresiasi atas partisipasinya untuk mewujudkan pelatihan ini.

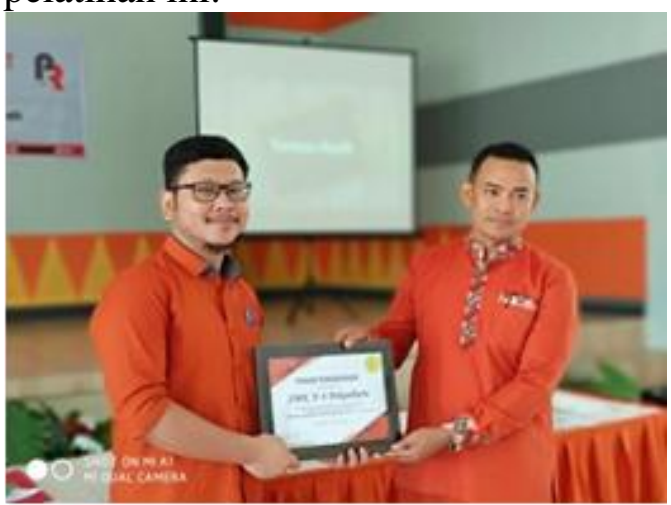

Gambar 4.5 Penyerahan Piagam Penghargaan kepadap Wakil Humas Sekolah SMK N 4 Pekanbaru

\section{SIMPULAN}

Keberadaan humas pada setiap institusi, lembaga, organisasi, perusahaan ataupun sekolah merupakan bagian yang paling penting karna dapat menjadi pondasi paling dasar dalam membentuk nama baik ataupun menjaga nama baik yang telah dibentuk. Berbeda bentuk institusi maka akan berbeda pula peran humas tersebut diperankan. Khusus untuk sekolah maka peran humas diperankan oleh setiap elemen yang ada di sekolah tersebut, baik oleh guru, pegawai sekolah, ataupun siswa siswi dari sekolah tersebut dengan cara menceritakan setiap berita baik yang dimiliki oleh sekolah tersebut dan memperbaiki berita buruk yang beredar di masyarakat dengan cara mengkonfirmasi berita sebenarnya. Dengan adanya kegiatan pengabdian ini diharapkan dapat membantu Sekolah dalam membangun citra baik dan diharapkan pihak sekolah benarbenar dapat mengaplikasikan ilmu yang telah diberikan oleh pemateri sebelumnya.

\section{DAFTAR PUSTAKA}

[1] Kelayakan Perguruan Tinggi, 
Data dari LPPM UMRI, 2017

[2] Gomes, Faustino Cardoso. 2005.

[3] Manajemen Sumber Daya Manusia. Yogyakarta : Penerbit Andi

[4] Oliver, Sandra. 2007. Strategi Public Relation. Jakarta: Esensi Erlangga Group.

[5] Rahmat, Abdul. 2006. Manajemen Humas Sekolah. Yogyakarta : Penerbit Media Akademi

[6] S. K, Bonar. (1993). Hubungan Masyarakat Modern : Public Relations. Jakarta: Rineka Cipta

[7] Siagian, Sondang. 2004. Organisasi Kepemimpinan dan Perilaku Administrasi. Jakarta: PT. Gunung Agung.

[8] Umar, H. 2003. Evaluasi Kinerja Perusahaan. Jakarta : Gramedia Pustaka Utama

[9] Veithzal, Rivai. 2005. Manajemen Sumber Daya Manusia. Jakarta: Raja Grafindo Persada.

[10] Website SMK N 4 Pekanbaru, http://www.smknegeri4pekanbaru. sch. id/ 